\title{
Advancing diagnosis, care and treatment for people with neuromuscular diseases around the world: a network of excellence to catalyse research infrastructure globally
}

\author{
Kate Bushby \\ From 5th European Conference on Rare Diseases (ECRD 2010) \\ Krakow, Poland. 13-15 May 2010
}

The TREAT-NMD (Translational Research Europe: Assessment and Treatment of Neuromuscular Diseases) network was initiated in January 2007. With 21 partners encompassing clinical and research centres of excellence in the field together with industrial and advocacy partners, the NoE was launched in response to the need for infrastructure to support a growing translational agenda in the field of neuromuscular diseases (NMD), supported by a strong group of advocacy organisations. From the outset, TREAT-NMD has embraced the need to work on a truly international stage by developing partnerships with groups across the world. This approach has led to international collaborations on infrastructure projects such as the definition of animal models for preclinical studies in NMD, patient registries and biobanks, a care and trial site registry, harmonised standards of care, standardised outcome measure assessments and ethical and regulatory interactions. The network has also initiated a new committee to advise on the multifaceted issues facing drug development in NMD- the TREAT-NMD advisory committee on therapeutics or TACT. From an initial focus on Duchenne muscular dystrophy and spinal muscular atrophy, the utility of the tools developed through the network is now recognised across a wide range of NMD and the "toolkits" generated are also relevant to other rare diseases with the need to address the pathway to therapy delivery.

EU investment in the network has provided a model which has added enormous value to the field. This is

Correspondence: Kate.bushby@ncl.ac.uk

Newcastle University, UK, TREAT-NMD co-ordinator, Institute of Human Genetics, Central Parkway, Newcastle upon Tyne NE1 3BZ, UK reflected in industrial investment in the tools of the network as well as the ability to generate additional grant income through the utilisation of the newly available infrastructure. Guaranteeing the sustainability of such successful infrastructure projects is an important consideration for the future.

Published: 19 October 2010

doi:10.1186/1750-1172-5-S1-013

Cite this article as: Bushby: Advancing diagnosis, care and treatment for people with neuromuscular diseases around the world: a network of excellence to catalyse research infrastructure globally. Orphanet Journal of Rare Diseases 2010 5(Suppl 1):013.
Submit your next manuscript to BioMed Central and take full advantage of:

- Convenient online submission

- Thorough peer review

- No space constraints or color figure charges

- Immediate publication on acceptance

- Inclusion in PubMed, CAS, Scopus and Google Scholar

- Research which is freely available for redistribution

Submit your manuscript at www.biomedcentral.com/submit
Biomed Central 